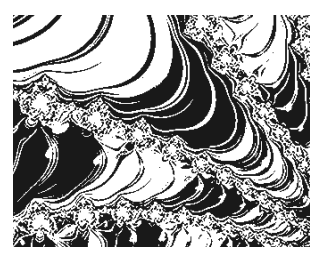

https://doi.org/10.5559/di.29.3.04

\title{
RELATIONSHIP SATISFACTION IN HOMOSEXUAL AND HETEROSEXUAL COUPLES: A DYADIC MODEL
}

Nina BRKIĆ-JOVANOVIĆ

Faculty of Medicine, University of Novi Sad, Novi Sad

Milica LAZIĆ, Ivan JERKOVIĆ, Ivana MIHIĆ

Faculty of Philosophy, University of Novi Sad, Novi Sad

Bojana PERIĆ-PRKOSOVAČKI

Faculty of Medicine, University of Novi Sad, Novi Sad

UDK: 159.942 .2

177.61

Izvorni znanstveni rad

Primljeno: 13. 7. 2018.

Rooted in Huston's (2000) model of adjustment in romantic relationships, the present study examined differences in individual and relationship characteristics and the predictive value of those characteristics for relationship satisfaction, regarding four groups of participants, based on gender and sexual orientation. The sample included a total of 100 heterosexual couples and 50 male and female homosexual couples each. Of the individual characteristics, need for affect achieves significant both actor and partner effects on relationship satisfaction in all subsamples, except for heterosexual women. A personal expression of love achieves both actor and partner effects on relationship satisfaction for heterosexual and homosexual men. The partner's expression of love (actor effect) on relationship satisfaction was registered in all groups, except for homosexual men. The present study offers the possibility of integrating knowledge of the differences between heterosexual and homosexual couples in the context of the model of adjustment in romantic relationships.

Keywords: romantic relationship satisfaction, sexual orientation, individual differences, relationship characteristics, dyadic model

Nina Brkić-Jovanović, University of Novi Sad,

Faculty of Medicine, Department of Psychology,

Hajduk Velikova 3, 21000 Novi Sad, Serbia. 
Over the past few decades a considerable amount of effort has been spent in exploring factors that have contributed to satisfaction in a romantic relationship (Hocking, Simons, Simons, \& Freeman, 2018; Sadikaj, Moskowitz, \& Zuroff, 2015; Schoenfeld, Loving, Pope, Huston, \& Štulhofer, 2017), with the objective of discovering personal and relationship characteristics contributing to the stability, satisfaction, and longevity of heterosexual relationships. Meanwhile, interest in studies examining satisfaction with romantic relationships in homosexual couples is increasing (Barringer \& Gay, 2017; Borneskog, Skoog Svanberg, Lampic, \& Sydsjö, 2012; Markey, Markey, Nave, \& August, 2014). Up till now, studies were more focused on verifying whether there are differences in relationship satisfaction, personality characteristics, ways of choosing a romantic partner, and relationship characteristics between homosexual and heterosexual couples. More recent studies point to the significance of research using couple-level and dyadic data analysis that take into account actor and partner effects in romantic relationships (Yucel, 2018).

In order to differentiate potential predictors, we used the model of adjustment in romantic relationships (Huston, 2000). At least three components that determine the course and outcome of romantic relationships are hypothesized by this model. It is a multidisciplinary model allowing for a comprehensive investigation of marital and other romantic relationships. Several important determinants of this model have led us to select it as a theoretical frame for our study. Huston (2000) regards it as universal and applicable to all relationships similar to marital ones, regardless of the partners' gender and sexual orientation. Thus far, it has been used as a theoretical framework for many studies and it has proven to be very useful in creating intervention programs for heterosexual couples (Halford, 2011; Kayser \& Rao, 2006; Crawford, Houts, Huston, \& George, 2002). It is classified as an ecological model, since it observes patterns of behavior in romantic relationships in their environmental realm, but also as a socio-psychological one since it deals with individual characteristics of partners in the context of social interactions within a romantic relationship. The model defines satisfaction as an outcome of a romantic relationship, which implies an overall assessment of the level of positive emotions experienced within the relationship (Huston, 2000).

The first component of the model entails individual characteristics, primarily the personality traits of each partner. Based on empirical examinations carried out so far within the model of adjustment in the romantic relationships framework, we have included the following individual characteristics 
DRUŠ. ISTRAŽ. ZAGREB GOD. 29 (2020), BR. 3, STR. 413-430

BRKIĆ-JOVANOVIĆ, N. ET AL.:

RELATIONSHIP. . in our study: romantic attachment (Brennan, Clark, \& Shaver, 1998), masculine/feminine personality features (Spence \& Buckner, 2000), need for affect (Maio \& Esses, 2001), and attitude toward gender roles (Huston, 2000).

Interactions between romantic partners represent the second component of the model. Changes in partner interactions and behavioral patterns also lead back to changes in individual attitudes and characteristics (Huston, 2000). Based on the model of adjustment in romantic relationships, the second domain consists of variables representing a persons' perception of partner interactions (Huston, 2000). This study includes three such variables: perception of love (Hendrick \& Hendrick, 1997), ways of showing love (Huić, Kamenov, Jugović, \& Huston, 2010), and quality of sexual interaction (Bartolac, Kamenov, \& Petrak, 2011).

The third component of the model represents the influence of a wider social environment. This component is described by the author of the model as a social, cultural, and physical environment in which a romantic relationship exists and includes affiliation to certain groups and subcultures as an important parameter (Huston, 2000), as was the case with sexual orientation in our study.

Although the model's author considers it to be universal, it was empirically validated primarily in studies on couples with heterosexual orientation, while the confirmation of its functionality on either male or female homosexual relationships is lacking. The variables included in our study correspond to those pertaining to the domain of individual and relationship characteristics tested for their predictive role in the process of examining the model in the original study (Huston, 2000), while we consider belonging to a subsample based on sexual orientation to be the third domain of influence.

Most studies show homosexual relationships to be similar to heterosexual ones on many dimensions, such as: pattern of facial preferences (Ciocca et al., 2014), the behavioral pattern of showing love in a relationship (Haas \& Stafford, 1998), the effect of gender roles on the process of communication (Julien, Arellano, \& Turgeon, 1997), the association of dependence on the romantic partner and the quality of the relationship (Kurdek \& Schmitt, 1986a), the association of the quality of the relationship, and the developmental phase of the romantic relationship (Kurdek \& Schmitt, 1986b). The same level of emotional expressiveness, intimacy, conflict, commitment, and relationship satisfaction was observed in both homosexual and heterosexual romantic relationships (Kurdek, 1998, 2001, 2004). The several studies that have examined predictors of satisfaction indicate that similar variables have predictive 
DRUŠ. ISTRAŽ. ZAGREB GOD. 29 (2020), BR. 3, STR. $413-430$

BRKIĆ-JOVANOVIĆ, N. ET AL.:

RELATIONSHIP... value in both groups. For example, the study by Malouff and colleagues (Malouff, Thorsteinsson, Schutte, Bhullar, \& Rooke, 2010) shows that one of the positive predictors of relationship satisfaction in both homosexual and heterosexual couples is a high score in trait agreeableness in both partners. However, this study did not test for differences in predictive values with regard to sexual orientation. Perceived sexual orientation similarity was not directly related to any of the counseling-related criterion variables (Stracuzzi, Mohr, \& Fuertes, 2011).

Other studies point to the existence of differences between male homosexual couples, female homosexual couples, and heterosexual couples which weaken the possibility of generalizing the existing models and theories on all three types of relationships (Kurdek, 2001). Individuals from the homosexual population have less family support (Kurdek, 2001), and numerous studies confirm gender roles as an important predictor of satisfaction in a relationship (Huston, 2000). Furthermore, emotional and sexual satisfaction was significantly different across sexual orientation groups (Mark, Garcia, \& Fisher, 2015). Lesbians and gay men reported higher levels of connection to ex serious-relationship partners than heterosexual individuals (Harkless, \& Fowers, 2005).

\section{THE PRESENT STUDY}

The purpose of the current study was twofold: 1) to check if there are any differences in individual and relationship characteristics between four groups of participants, which were formed based on gender and sexual orientation, 2) to determine the predictive value of individual and relationship characteristics for relationship satisfaction, irrespective of participant subsamples. As this model assumes that belonging to a subgroup represents a significant factor, we expect to obtain differences in satisfaction with a romantic relationship and its presumed predictors. The generalizability of the model suggested by its authors leads us to hypothesize that processes within relationships remain the same regardless of sexual orientation.

\section{METHOD}

\section{Sample}

The sample consisted of 400 participants, out of which 200 were male and 200 female, and all were over 18 years of age $(M=25.81, S D=6.71)$, forming 200 romantic couples (dyads). The sample consisted of 100 heterosexual couples and 50 male and female homosexual couples, respectively. All participants lived in the Republic of Serbia and were involved in romantic relationships they described as stable at the time, 
DRUŠ. ISTRAŽ. ZAGREB GOD. 29 (2020), BR. 3, STR. 413-430

BRKIĆ-JOVANOVIĆ, N. ET AL.:

RELATIONSHIP. . but did not cohabit while the study was being conducted. The inclusion criteria were: the duration of a romantic relationship of over a year $(M=37.61$ months, $S D=38.87)$, heterosexual couples not having children, and homosexual participants not having children from previous heterosexual relationships. Participants were recruited with the aid of non-government organizations dealing with LGBT issues. All information was collected with the informed consent from both partners and approval from the Ethical committee of the Faculty of Philosophy in Novi Sad. We tested differences by age and length of relationship and did not find statistically significant differences between groups. Most participants have completed formal education and the majority were employed. There were 50 unemployed participants with an approximately equal representation in all three groups.

\section{Instruments}

All participants completed the same battery of scales. In order to maintain anonymity and respect for participants' privacy, only information on age, gender, sexual orientation, and duration of relationship was collected on both partners.

The Experiences in Close Relationships Inventory - Revised (ECRI-R; Brennan et al., 1998; Kamenov \& Jelić, 2003) is a scale assessing two dimensions of emotional attachment: anxiety ("I am preoccupied with the worry of potentially losing my partner") and avoidance ("I get nervous when my partner becomes too close emotionally"). The modified and abbreviated version was used in this study (Kamenov \& Jelić, 2003) consisting of 18 items, nine per subscale, with a seven-point answering scale. The reliability of each dimension was satisfactory in our study, both on the entire sample and on specific subsamples with $\alpha$ values ranging from 0.82 to 0.88 for anxiety and 0.81 to 0.84 for avoidance.

Personal Attributes Questionnaire (PAQ; Spence, Helmreich, \& Stapp, 1974) is a questionnaire intended for the assessment of which personality gender stereotype an individual belongs to. The questionnaire consists of 16 items divided into two dimensions: the dimension of expressiveness (femininity) and instrumentality (masculinity), with participants being asked to assess to what degree a particular trait described their personality. The reliability of the expressiveness/femininity scale was found to be satisfactory both on the entire sample and on specific subsamples with $\alpha$ values ranging from 0.79 to 0.84 . The reliability of the instrumentality/masculinity subscale on the entire sample and on specific subsamples is questionable ( $\alpha$ values from 0.61 to 0.68 ). 
DRUŠ. ISTRAŽ. ZAGREB GOD. 29 (2020), BR. 3, STR. $413-430$

BRKIĆ-JOVANOVIĆ, N. ET AL.:

RELATIONSHIP...
Attitudes toward Gender Roles Scale (ATGR; Kamenov, Jelić, \& Jugović, 2009) is a scale intended to assess attitudes toward gender roles. It consists of 12 items (e.g. "The most important decisions in the family should be made by the man") with participants expressing their agreement on a seven-point Likert-type scale. High scores on this scale point to a more egalitarian attitude toward gender roles, while lower ones to a more traditional attitude. The internal consistency of this scale was satisfactory in our study, both for the complete sample and for specific subsamples ranging from $\alpha=0.87$ to 0.88 .

Need for Affect Scale (NFAS; Maio \& Esses, 2001) is a questionnaire used for assessing the need to experience emotions, defined as a general motivation that individuals experience to embrace or avoid situations, as well as activities that can trigger emotions in themselves or in other people. The scale consists of 16 items (e.g. "Emotions help people cope with life") to which participants respond on a seven-point Likert-type scale. The authors of the scale reported high internal consistency, good construct validity, and test-retest reliability (Maio \& Esses, 2001). In our study, the reliability of this scale was satisfactory with $\alpha$ values ranging from 0.80 to 0.83 .

The Love Scale (LS; Braiker \& Kelly, 1979) determines a person's assessment of love for their romantic partner, how much they are "meant for each other," how loyal a person is to the partner, etc. A participant's task is to express his/her level of agreement with the items on a nine-point Likert-type scale. Higher scores indicate greater intensity of perceived love, loyalty, and sense of belonging with the partner. The reliability of this scale was satisfactory in our study and $\alpha$ was in the range of 0.85 to 0.88 , depending on the subsample.

Ways of Showing Love (WSL; Huić et al., 2010) is a scale intended for assessment of the way a person expresses love and how their romantic partner expresses it. It consists of 49 statements which describe different ways in which love can be shown (e.g. "When we're not together, I send or leave him love notes"). The participants' task was to indicate how much these statements related to them and then assess how much the statements are true for their romantic partner on a five-point Likert-type scale. The items have two forms: How I show love and How my partner shows love. The reliability of the entire scale in both forms on the entire sample, as well as on subsamples, was high with $\alpha$ values ranging from 0.91 to 0.92 for the participant's own expression of love and 0.94 to 0.96 for the partner's expression of love. 
DRUŠ. ISTRAŽ. ZAGREB GOD. 29 (2020), BR. 3, STR. 413-430

BRKIĆ-JOVANOVIĆ, N. ET AL.:

RELATIONSHIP..

\section{Data analysis}

Quality of Sexual Interaction (Bartolac et al., 2011) is a scale which assesses the degree to which a person's needs and wishes are fulfilled in a sexual relationship with a partner. The questionnaire consists of six items (e.g. "During sexual intercourse, your partner provides you with the exact stimulation you need") with a five-point Likert-type answering scale. The reliability of this scale in our study was not satisfactory for the entire sample and for various subsamples, as it ranged from $\alpha=0.52$ to $\alpha=0.58$. The analysis of the contribution of single questions within the scale showed that two items significantly lowered the reliability of the whole scale. By removing these items, the reliability was raised up to 0.78 to 0.83 , depending on whether the entire sample was taken into account or specific subsamples.

Scale of General Marital Satisfaction is a single-item measure ("How satisfied are you with your relationship overall?") that assesses general satisfaction with the romantic relationship. Participants respond to this item on a nine-point Likert-type scale. This approach attempts to obtain a global assessment of how much pleasure romantic partners get from their relationship, disregarding possible daily or periodical oscillations, as well as a potentially ambivalent relationship toward some personality traits of the partner or some characteristics of the relationship itself. To achieve this, the question on relationship satisfaction was presented in the middle of the battery, following the questions on individual characteristics and preceding those on the relationship.

We used the Actor-Partner Interdependence Model (APIM) (Kenny, Kashy, \& Cook, 2006) in Mplus 7.31 (Muthen \& Muthen, 2015) to test our hypothesized structural models. APIMs (Kenny et al., 2006) are statistical methods making it possible to examine how an individual's predictor variables simultaneously and independently relate to their own criterion variable and to the partner's criterion variable. Accordingly, the APIM model provides separate but simultaneous measures of actor and partner effects. In this example, actor effects capture the association between individual's perception of personal and relational characteristics and individual's romantic relationship satisfaction after controlling for interdependency in the dataset. Similarly, partner effects measure the association between individual's perception of personal and relational characteristics and romantic relationship satisfaction of their partners, after controlling for interdependency in the dataset (Fincham \& Cui, 2010). Three APIM models were conducted, out of which one model was for distinguishable dy- 
DRUŠ. ISTRAŽ. ZAGREB GOD. 29 (2020), BR. 3, STR. $413-430$

BRKIĆ-JOVANOVIĆ, N. ET AL.:

RELATIONSHIP... ads (heterosexual couples), and two models were for indistinguishable dyads (male and female homosexual couples).

The significance of differences between groups formed on the basis of gender and sexual orientation was tested by using multivariate analysis of variance (MANOVA), more precisely the Brown-Forsythe test.

\section{RESULTS}

(1) TABLE 1

Descriptive statistics and group differences
Descriptive statistics and the testing of the significance of differences between groups formed on the basis of gender and sexual orientation were obtained by using multivariate analysis of variance (MANOVA) (Table 1). The unequal sample groups' sizes dictated the use of the Brown-Forsythe F test. On measures of expressivity, personal expression of love, a partner's expression of love, and on the quality of sexual interaction, there were no statistically significant differences across subsamples based on gender and sexual orientation. Men of homosexual orientation reported the lowest level of relationship satisfaction, while the highest-level satisfaction was reported by both men and women of heterosexual orientation.

\begin{tabular}{|c|c|c|c|c|c|c|c|c|c|c|}
\hline & \multicolumn{2}{|c|}{$\begin{array}{l}\text { Women } \\
\text { of het- } \\
\text { erosexual } \\
\text { orientation }\end{array}$} & \multicolumn{2}{|c|}{$\begin{array}{l}\text { Men } \\
\text { of het- } \\
\text { erosexual } \\
\text { orientation }\end{array}$} & \multicolumn{2}{|c|}{$\begin{array}{l}\text { Women } \\
\text { of homo- } \\
\text { sexual } \\
\text { orientation }\end{array}$} & \multicolumn{2}{|c|}{$\begin{array}{l}\text { Men } \\
\text { of homo- } \\
\text { sexual } \\
\text { orientation }\end{array}$} & \multicolumn{2}{|c|}{$\begin{array}{l}\text { Brown- } \\
\text {-Forsythe } \eta^{2} \\
F\end{array}$} \\
\hline Relationship satisfaction & $8.07^{\mathrm{b}}$ & 1.06 & $8.12^{\mathrm{b}}$ & 1.12 & $7.95^{\mathrm{b}}$ & 1.02 & $7.54^{\mathrm{a}}$ & 1.57 & $4.68^{* *}$ & 0.034 \\
\hline $\begin{array}{l}\text { Individual characteristics } \\
\text { Anxiety } \\
\text { Avoidance } \\
\text { Expressivity } \\
\text { Instrumentality } \\
\text { Gender roles attitude } \\
\text { Need for affect }\end{array}$ & $\begin{array}{l}24.49^{\mathrm{b}} \\
17.72^{\mathrm{b}} \\
4.05 \\
3.40^{\mathrm{b}} \\
6.18^{\mathrm{b}} \\
14.87^{\mathrm{a}, \mathrm{b}}\end{array}$ & $\begin{array}{l}10.42 \\
7.62 \\
0.66 \\
0.57 \\
0.86 \\
14.17\end{array}$ & $\begin{array}{l}24.46^{\mathrm{b}} \\
21.77^{\mathrm{a}} \\
3.82 \\
3.70^{\mathrm{a}} \\
5.45^{\mathrm{a}} \\
10.49^{\mathrm{b}}\end{array}$ & $\begin{array}{l}10.77 \\
10.18 \\
0.61 \\
0.56 \\
1.12 \\
12.89\end{array}$ & $\begin{array}{l}29.59^{a} \\
22.73^{a} \\
3.97 \\
3.51^{a, b} \\
6.37^{b} \\
16.12^{a}\end{array}$ & $\begin{array}{l}12.39 \\
10.61 \\
0.71 \\
0.55 \\
0.90 \\
15.43\end{array}$ & $\begin{array}{l}33.02^{\mathrm{a}} \\
24.35^{\mathrm{a}} \\
3.94 \\
3.51^{\mathrm{a}, \mathrm{b}} \\
5.57^{\mathrm{a}} \\
11.54^{\mathrm{a}, \mathrm{b}}\end{array}$ & $\begin{array}{l}12.89 \\
10.15 \\
0.65 \\
0.49 \\
1.16 \\
14.17\end{array}$ & $\begin{array}{l}12.61^{* *} \\
3.11^{*} \\
2.01 \\
5.16^{* *} \\
19.68^{* *} \\
3.44^{*}\end{array}$ & $\begin{array}{l}0.089 \\
0.061 \\
0.015 \\
0.038 \\
0.13 \\
0.026\end{array}$ \\
\hline $\begin{array}{l}\text { Relationship characteristics } \\
\text { Perception of love } \\
\text { Personal expression of love } \\
\text { Partner's expression of love } \\
\text { Quality of sexual interaction }\end{array}$ & $\begin{array}{l}8.25^{\mathrm{b}} \\
196.76 \\
164.13 \\
17.69\end{array}$ & $\begin{array}{l}0.77 \\
20.10 \\
18.89 \\
2.68\end{array}$ & $\begin{array}{l}8.20^{\mathrm{b}} \\
202.11 \\
157.65 \\
17.53\end{array}$ & $\begin{array}{l}0.81 \\
22.97 \\
21.84 \\
2.71\end{array}$ & $\begin{array}{l}7.81^{\mathrm{a}} \\
204.60 \\
162.21 \\
18.17\end{array}$ & $\begin{array}{l}1.09 \\
24.24 \\
26.07 \\
2.83\end{array}$ & $\begin{array}{l}7.76^{a} \\
199.46 \\
158.85 \\
17.29\end{array}$ & $\begin{array}{l}1.16 \\
23.37 \\
22.53 \\
2.71\end{array}$ & $\begin{array}{l}7.130 * * \\
2.474 \\
2.850 \\
0.372\end{array}$ & $\begin{array}{l}0.048 \\
0.017 \\
0.020 \\
0.015\end{array}$ \\
\hline
\end{tabular}

Note: Standardized group means are as shown; ${ }^{*} p<0.05,{ }^{* *} p<0.01$; Within rows, means with different superscripts ( $a$ or $b$ ) are significantly different in pair-wise comparisons.

Participants of heterosexual orientation, regardless of their gender, report less anxiety as a dimension of emotional attachment compared to persons of homosexual orientation. In contrast to the dimension of anxiety where lower scores are obtained by those of homosexual orientation, the lowest scores for emotional attachment - avoidance are obtained by wo- 
DRUŠ. ISTRAŽ. ZAGREB GOD. 29 (2020), BR. 3, STR. 413-430

BRKIĆ-JOVANOVIĆ, N ET AL.:

RELATIONSHIP..

\section{Dyadic analysis}

men of heterosexual orientation while the remaining three groups do not significantly differ from each other in this aspect. On the scale of masculinity/instrumentality, men and women of homosexual orientation do not differ, and their scores do not diverge from those obtained by heterosexual participants. A statistically significant difference is only registered in heterosexual couples, where men score higher on this dimension than do women.

The grouping of values concerning gender role attitudes is observed not with regard to sexual orientation but with regard to gender. Women are generally more prone to an egalitarian attitude toward gender roles, while men, regardless of sexual orientation, are more inclined toward a traditional view of gender roles. This variable yielded the largest difference between groups, which reached high effect size.

Although most differences on the measure of need for affect are not statistically significant, it is evident that women of homosexual orientation have a more pronounced need for affect compared to men of heterosexual orientation.

Within the domain pertaining to the characteristics of relationships, statistically significant differences between groups are registered only regarding to the perception of love. Individuals of heterosexual orientation generally perceive a greater intensity of love in a romantic relationship, compared to those of homosexual orientation. The difference is only evident with regard to sexual orientation and not gender. However, it is a small effect size that should be noted.

The associations of individual characteristics with romantic relationship satisfactions were investigated using three Actor-Partner Independence Models: one distinguishable for heterosexual couples and two indistinguishable for both male and female homosexual couples. For heterosexual women, the model shows that individual characteristics have no influence on romantic relationship satisfaction (Table 2). By contrast, for heterosexual men, romantic relationship satisfaction is predicted by both personal $(\beta=0.33, p<0.01)$ and partner's $(\beta=0.19, p<0.05)$ need for affect. Patterns similar to those seen for men in heterosexual couples were also detected in male and female homosexual couples. Need for affect was found to have significant actor $(\beta=0.32, p<0.01)$ and partner effects $(\beta=0.21, p<0.05)$ on females' relationship satisfaction in homosexual relationships. In homosexual women, relationship satisfaction was found to correlate with their personal need for affect as well as that of their partner's. Higher levels on the measure of need for affect in an individual and their partner were followed by higher relationship satisfaction in this subgroup. Similarly, for men of homosexual orientation, 
DRUŠ. ISTRAŽ. ZAGREB GOD. 29 (2020), BR. 3, STR. $413-430$

BRKIĆ-JOVANOVIĆ, N. ET AL.:

RELATIONSHIP...

\section{(1) TABLE 2}

APIM models: role of individual characteristics in the prediction of both partners' relationship satisfaction actor $(\beta=0.32, p<0.01)$ and partner effects $(\beta=0.18, p<0.01)$ were found to be significant for the relation between need for affect and relationship satisfaction. Effect size for the actor effect of need for affect can be considered as moderate, while effect size for partner effect for the same predictor is weak. No actor and partner effects for other individual characteristics proved significant.

\begin{tabular}{llrrrrrrrr}
\hline Anxiety & Actor & -1.88 & -0.17 & -1.88 & -0.16 & -0.45 & -0.04 & -1.22 & -0.15 \\
Avoidance & Partner & 1.12 & 0.12 & 0.07 & 0.01 & -0.35 & -0.03 & -1.53 & -0.17 \\
& Actor & -0.05 & -0.01 & 1.67 & 0.21 & 1.99 & 0.20 & 0.40 & 0.05 \\
Expressiveness & Partner & -0.53 & -0.06 & -1.50 & -0.18 & -0.83 & -0.08 & 0.26 & 0.03 \\
& Actor & 0.09 & 0.14 & 0.09 & 0.18 & 0.04 & 0.06 & 0.05 & 0.11 \\
Instrumentality & Partner & -0.08 & -0.15 & 0.03 & 0.05 & 0.05 & 0.08 & 0.02 & 0.05 \\
& Actor & 0.11 & 0.21 & 0.07 & 0.14 & 0.03 & 0.06 & 0.03 & 0.10 \\
Gender roles attitude & Partner & -0.10 & -0.20 & 0.07 & 0.14 & 0.04 & 0.08 & 0.01 & 0.04 \\
& Actor & -0.11 & -0.13 & -0.08 & -0.10 & 0.02 & 0.02 & 0.04 & 0.08 \\
Need for affect & Partner & 0.05 & 0.06 & 0.02 & 0.03 & 0.20 & 0.18 & 0.05 & 0.08 \\
& Actor & 0.11 & 0.14 & 0.29 & $0.33^{* *}$ & 0.32 & $0.32^{* *}$ & 0.22 & $0.32^{*}$ \\
& Partner & 0.03 & 0.04 & 0.18 & $0.19^{*}$ & 0.21 & $0.21^{*}$ & 0.12 & $0.18^{*}$
\end{tabular}

${ }^{*} p<0.05,{ }^{* *} p<0.01$

The next three APIM models tested the relationships between the relational characteristics and romantic relationship satisfaction for both heterosexual couples and male and female homosexual couples (Table 3). For heterosexual women, only personal perception of a partner's expression of love $(\beta=0.42, p<0.01)$ was a significant predictor of romantic relationship satisfaction. Similarly, heterosexual men $(\beta=0.25$, $p<0.01)$ and homosexual women $(\beta=0.37, p<0.01)$ expressed higher relationship satisfaction if they perceived their partner's expression of love as higher. Significant actor and partner effects were found for the relationship between personal expression of love and relationship satisfaction for both heterosexual and homosexual men. Heterosexual and homosexual men reported more satisfaction with their romantic relationships if they showed love and their partners also showed love. Along with personal expressions of love, the perception of love $(\beta=0.31, p<0.01)$ is also a significant predictor of relationship satisfaction in homosexual men. Effect size for all significant effects can be assessed as moderate. Nonsignificant paths were found for quality of sexual interaction and other unmentioned variables. 
(1) TABLE 3

APIM models: role of relational characteristics in the prediction of both partners' relationship satisfaction

\begin{tabular}{llrrrrrrrl}
\hline Perception of love & Actor & 0.70 & 0.06 & 0.32 & 0.03 & 0.05 & 0.01 & 4.62 & $0.31^{* *}$ \\
& Partner & -1.11 & -0.10 & -2.13 & -0.18 & 2.28 & 0.21 & 0.12 & 0.01 \\
Personal expression & Actor & -0.67 & -0.06 & -2.52 & $0.26^{* *}$ & 0.22 & 0.03 & 3.90 & $0.27^{* *}$ \\
of love & Partner & -0.80 & -0.08 & 2.68 & $0.27^{* *}$ & -1.51 & -0.17 & -2.93 & $0.20^{*}$ \\
Partner's expression & Actor & 0.31 & $0.42^{* *}$ & -0.80 & $0.25^{* *}$ & 0.23 & $0.37^{* *}$ & 0.05 & 0.07 \\
of love & Partner & 0.04 & 0.05 & -0.67 & 0.17 & 0.07 & 0.11 & -0.12 & -0.15 \\
$\begin{array}{l}\text { Quality of sexual } \\
\text { interaction }\end{array}$ & Actor & 0.05 & 0.08 & 0.04 & -0.01 & -0.02 & -0.04 & 0.01 & 0.02 \\
& Partner & 0.02 & 0.04 & 0.31 & 0.05 & 0.09 & 0.19 & -0.06 & -0.10 \\
\hline
\end{tabular}

${ }^{*} p<0.05,{ }^{* *} p<0.01$
Heterosexual Heterosexual Homosexual Homosexual women men women men

В $\quad \begin{array}{lllllll}\text { B } & \beta & \text { B } & \beta & \text { B } & \beta\end{array}$

\section{DISCUSSION}

Two main hypotheses were defined in our study. First, we hypothesized that differences exist in interpersonal characteristics and relationship characteristics, as well as in the level of satisfaction within a romantic relationship between our four subgroups of participants formed on the basis of gender and sexual orientation. The second hypothesis was that individual and relationship characteristics have a significant predictive value for relationship satisfaction, irrespective of the participant subsample. We expected to find differences in variables measured but anticipated too that the relationship between predictor and criterion variables would remain the same. We will discuss the particular results for each of the hypotheses separately.

First, we attempted to answer the question of whether heterosexual couples differ significantly from homosexual couples in relationship satisfaction. At the very beginning, it is important to emphasize that in our study all participants as a group show a high degree of satisfaction with their relationships, which can be explained by the fact that all the relationships are still in the first developmental phase in which high satisfaction with the relationship is expected (Glenn, 1998). Peplau and Fingerhut (2007) mention one of the existing stereotypes associated with homosexual couples as being unhappy and dissatisfied in their romantic relationships. Our study has confirmed that this is in fact just a stereotype. However, a difference in satisfaction is observed with regard to sexual orientation in a way that persons from the heterosexual population and women from the homosexual population are more satisfied with their relationships than men from 
DRUŠ. ISTRAŽ. ZAGREB GOD. 29 (2020), BR. 3, STR. $413-430$

BRKIĆ-JOVANOVIĆ, N. ET AL.:

RELATIONSHIP... the homosexual population. We postulated numerous reasons for this that begin with pronounced social marginalization (Hatzenbuehler \& Pachankis, 2016; Lewis, Derlega, Griffin, \& Krowinski, 2003; Peplau \& Beals, 2004) and lack of support from the nuclear family (Kurdek, 2001; Soler, Caldwell, Córdova, Harper, \& Bauermeister, 2018), and go all the way to the importance of gender roles with regard to satisfaction in a partner relationship (Huston, 2000; Matud, Bethencourt, \& Ibáñez, 2014).

When intergroup differences are observed, the results show that heterosexual women are the least avoiding compared to all other groups. However, all groups have a very low score on this dimension. These results can be explained by gender roles which teach men to be more autonomous, to show less emotion, to be independent and assertive while they teach women to be close, intimate, and warm (Strickland, 2010).

Our study confirmed gender differences in attitudes toward gender roles which were obtained in previous studies (Brkić, Mihić, Karić, \& Jerković, 2013) in a way that women are significantly more egalitarian in their attitudes toward gender roles than men. The findings of this study now further support this hypothesis by showing that egalitarianism in women is not influenced by sexual orientation.

The results of this study show no differences in femininity between the groups. This is important because it indicates that homosexual men are no more feminine than heterosexual men, but also speaks against homosexual women being less feminine than heterosexual women. Finding no differences in femininity, i.e. expressiveness, between groups is opposed to the existing stereotypes of homosexual persons, but it is also opposed to the attitude that heterosexual women, in accordance with gender roles, are more expressive than heterosexual men (Liben, Bigler, Ruble, Martin, \& Powlishta, 2002). Regarding the dimension of masculinity, it can be seen that women and men of homosexual orientation are no different to women and men of heterosexual orientation. This finding disputes the stereotype of differences between homosexual and heterosexual persons. The only difference that was found was between men and women of heterosexual orientation, which points to the significance of gender roles in the socialization of heterosexual men (Strickland, 2010).

Numerous studies confirm gender differences in the expression of need for affect, and it is considered that processes of social learning can lead to these differences (Huić, 2012; Huić et al., 2010; Leone \& Presaghi, 2007; Maio \& Esses, 2001; Mihić \& Huić, 2012). Our results confirm gender differences in experiencing emotions, but only between men of heterosexual orientation and women of homosexual orientation. 
DRUŠ. ISTRAŽ. ZAGREB GOD. 29 (2020), BR. 3, STR. 413-430

BRKIĆ-JOVANOVIĆ, N. ET AL.:

RELATIONSHIP..
Differences are observed in the perception of love and intimacy as well. Men and women of homosexual orientation have a lower perception of love in a relationship compared to men and women of heterosexual orientation. Another important finding of this study is that we found no significant differences in the assessment of sexual interaction quality. Also, the difference in the frequencies of love shown by a person and by the partner is nonexistent between the observed four groups of participants.

These results speak in favor of the existence of significant differences in most tested constructs with regard to gender and sexual orientation. The hypothesis that belonging to a particular subgroup defines certain individual characteristics and behaviors was thus confirmed.

When all individual characteristics are included in dyad-level models of prediction of relationship satisfaction, they do not significantly predict satisfaction with the romantic relationship and neither actor, nor partner effects are registered, except when the need for affect is concerned. In women of heterosexual orientation, individual characteristics show no effect on satisfaction, while in other subgroups the need for affect shows actor and partner effects. The processes remain the same in all three groups of participants: with an increase in one's own, and in the partner's need for affect, there is an increase in relationship satisfaction.

Where relationship characteristics are concerned, a significant contribution to satisfaction with the romantic relationship is registered in all theoretically hypothesized predictors, except for the quality of sexual interaction. Predictors of relationship satisfaction differ with regard to gender and sexual orientation, although certain similarities have been observed.

Our study confirmed the importance of the way in which love is shown, in the sense of frequency, and for the satisfaction with a romantic relationship in men regardless of sexual orientation. Both actor and partner effects were observed. In persons of heterosexual orientation, as well as women of homosexual orientation, the actor effect is significant for relationship satisfaction in the perception of the extent to which a partner shows love. In homosexual men, the individual perception of love contributes to satisfaction within a romantic relationship.

These findings do not support the viewpoint that the functioning of romantic relationships and the relationship of variables within the tested model is constant irrespective of sexual orientation. Belonging to a subgroup that is formed based on sexual orientation seems to determine effect sizes between predictors and the criterion. These results confirm the position taken by the author of the theoretical model 
DRUŠ. ISTRAŽ. ZAGREB GOD. 29 (2020), BR. 3, STR. $413-430$

BRKIĆ-JOVANOVIĆ, N. ET AL.:

RELATIONSHIP...

\section{REFERENCES}

which postulates the mutual effects of the three domains on each other. They also substantiate the claims that social context can change the intensity and way in which the remaining two domains influence relationship satisfaction.

This study has several significant limitations that need to be observed. First of all, relationship satisfaction was extremely high in most participants belonging to all three sample groups, which is an important finding to be considered when the results of this study are concerned. Also, participants were recruited with the help of non-government organizations dealing with LGBT issues. At least one of the partners had some sort of association with these organizations, which limits the generalizability of results to homosexual couples who are at least minimally incorporated in the existing support systems. Also, a number of potential participants did not consent to being part of this study (around 30\%). Lastly, it is important to emphasize that in $70 \%$ of these cases, refusal was on both sides, while in $30 \%$ of couples who declined participation, only one of the partners did not wish to participate. This further limits the generalizability of the results.

Barringer, M. N., \& Gay, D. A. (2017). Happily religious: The surprising sources of happiness among lesbian, gay, bisexual, and transgender adults. Sociological Inquiry, 87(1), 75-96. https://doi.org/10.1111/ soin.12154

Bartolac, A., Kamenov, Ž., \& Petrak, O. (2011). Rodne razlike u obiteljskim ulogama, zadovoljstvu i doživljaju pravednosti s obzirom na tradicionalnost stava (Gender differences in family roles, satisfaction and perception of fairness with regard to the traditionality of gender attitudes). Revija za socijalnu politiku, 18(2), 175-194. https://doi.org/10. 3935/rsp.v18i2.998

Borneskog, C., Skoog Svanberg, A., Lampic, C., \& Sydsjö, G. (2012). Relationship quality in lesbian and heterosexual couples undergoing treatment with assisted reproduction. Human Reproduction, 27(3), 779-786. https://doi.org/10.1093/humrep/der472

Braiker, H. B., \& Kelley, H. H. (1979). Conflict in the development of close relationships. In R. Burgess \& T. Huston (Eds.), Social exchange in developing relationships (pp. 135-168). New York: Academic Press. https://doi.org/10.1016/B978-0-12-143550-9.50011-2

Brennan, K. A., Clark, C. L., \& Shaver, P. R. (1998). Self-report measurement of adult romantic attachment: An integrative overview. In J. A. Simpson \& W. S. Rholes (Eds.), Attachment theory and close relationships (pp. 46-76). New York: The Guilford Press.

Brkić, N., Mihić, I., Karić, T., \& Jerković, I. (2013). The ways of showing love, closeness and satisfaction in homosexual relationships: The importance of attachment. Applied Psychology, 6(4), 407-422. https://doi. org/10.19090/pp.2013.4.407-422 
DRUŠ. ISTRAŽ. ZAGREB GOD. 29 (2020), BR. 3, STR. 413-430

BRKIĆ-JOVANOVIĆ, N. ET AL.:

RELATIONSHIP...
Ciocca, G., Limoncin, E., Cellerino, A., Fisher, A. D., Gravina, G. L., Carosa, E., ... \& Di Stasi, S. M. (2014). Gender identity rather than sexual orientation impacts on facial preferences. The Journal of Sexual Medicine, 11(10), 2500-2507. https://doi.org/10.1111/jsm.12633

Crawford, D. W., Houts, R. M., Huston, T. L., \& George, L. J. (2002). Compatibility, leisure, and satisfaction in marital relationships. Journal of Marriage and Family, 64(2), 433-449. https://doi.org/10.1111/ j.1741-3737.2002.00433.x

Fincham, F. D., \& Cui, M. (Eds.) (2010). Romantic relationships in emerging adulthood. New York: Cambridge University Press. https://doi. org/10.1017/CBO9780511761935

Glenn, N. D. (1998). The course of marital success and failure in five American 10-year marriage cohorts. Journal of Marriage and the Family, 60(3), 569-576. https://doi.org/10.2307/353529

Haas, S. M., \& Stafford, L. (1998). An initial examination of maintenance behaviors in gay and lesbian relationships. Journal of Social and Personal Relationships, 15(6), 846-855. https://doi.org/10.1177/0265407 598156008

Halford, W. K. (2011). Marriage and relationship education: What works and how to provide it. New York: The Guilford Press.

Harkless, L. E., \& Fowers, B. J. (2005). Similarities and differences in relational boundaries among heterosexuals, gay men, and lesbians. Psychology of Women Quarterly, 29(2), 167-176. https://doi.org/10. 1111/j.1471-6402.2005.00179.x

Hatzenbuehler, M. L., \& Pachankis, J. E. (2016). Stigma and minority stress as social determinants of health among lesbian, gay, bisexual, and transgender youth: Research evidence and clinical implications. Pediatric Clinics, 63(6), 985-997. https://doi.org/10.1016/j.pcl.2016.07.003

Hendrick, S. S., \& Hendrick, C. (1997). Love and satisfaction. In R. J. Sternberg, \& M. Hojjat (Eds.), Satisfaction in close relationships (pp. 56-78). New York: The Guilford Press.

Hocking, E. C., Simons, R. M., Simons, J. S., \& Freeman, H. (2018). Adult attachment and drinking context as predictors of alcohol problems and relationship satisfaction in college students. The American Journal of Drug and Alcohol Abuse, 44(3), 339-347. https://doi.org/10. 1080/00952990.2017.1344682

Huić, A. (2012). Potreba za emocijama - doprinos valjanosti i efikasnijem mjerenju (Need for affect - validity and efficient measurement). Psihologijske teme, 21(2), 337-358.

Huić, A., Kamenov, Ž., Jugović, I., \& Huston, T. (2010). Need for affect in romantic relationships. Review of Psychology, 17(2), 168.

Huston, T. L. (2000). The social ecology of marriage and other intimate unions. Journal of Marriage and the Family, 62(2), 298-320. https://doi. org/10.1111/j.1741-3737.2000.00298.x

Julien, D., Arellano, C., \& Turgeon, L. (1997). Gender issues in heterosexual, gay and lesbian couples. In W. K. Halford \& H. J. Markman (Eds.), Clinical handbook of marriage and couples interventions (pp. 107-127). New York: Wiley. 
DRUŠ. ISTRAŽ. ZAGREB GOD. 29 (2020), BR. 3, STR. $413-430$

BRKIĆ-JOVANOVIĆ, N. ET AL.:

RELATIONSHIP...
Kamenov, Ž., \& Jelić, M. (2003). Validacija instrumenta za mjerenje privrženosti u različitim vrstama bliskih odnosa: Modifikacija Brennanovog inventara iskustva $\mathrm{u}$ bliskim vezama (Validation of adult attachment measure in various types of close relationships: Modification of Brennan's Experiences in Close Relationship Inventory). Suvremena psihologija, 6(1), 73-91.

Kamenov, Ž., Jelić, M. i Jugović, I. (2009). Skala stavova prema rodnim ulogama - ATGR (Attitudes towards Gender Roles Scale). Unpublished work.

Kayser, K., \& Rao, S. S. (2006). Process of disaffection in relationship breakdown. In M. A. Fine \& J. H. Harvey (Eds.), Handbook of divorce and relationship dissolution (pp. 201-221). Mahwah, NJ: Lawrence Erlbaum Associates Publishers.

Kenny, D. A., Kashy, D. A., \& Cook, W. L. (2006). Dyadic data analysis. New York: The Guilford Press.

Kurdek, L. A. (1998). Relationship outcomes and their predictors: Longitudinal evidence from heterosexual married, gay cohabiting, and lesbian cohabiting couples. Journal of Marriage and the Family, 60(3), 553-569. https://doi.org/10.2307/353528

Kurdek, L. A. (2001). Differences between heterosexual-nonparent couples and gay, lesbian, and heterosexual-parent couples. Journal of Family Issues, 22(6), 727-754. https://doi.org/10.1177/019251301022006004

Kurdek, L. A. (2004). Are gay and lesbian cohabiting couples really different from heterosexual married couples? Journal of Marriage and Family, 66(4), 880-900. https://doi.org/10.1111/j.0022-2445.2004.00060.x

Kurdek, L. A., \& Schmitt, J. P. (1986a). Relationship quality of gay men in closed or open relationships. Journal of Homosexuality, 12(2), 85-99. https://doi.org/10.1300/J082v12n02_06

Kurdek, L. A., \& Schmitt, J. P. (1986b). Early development of relationship quality in heterosexual married, heterosexual cohabiting, gay and lesbian couples. Developmental Psychology, 22(3), 305-309. https://doi.org/10.1037/0012-1649.22.3.305

Leone, L., \& Presaghi, F. (2007). Validity of the need for affect scales: Factorial structure, invariance and validity in the Italian context. TPM - Testing, Psychometrics, Methodology in Applied Psychology, 14(3-4), 117-134.

Lewis, R. J., Derlega, V. J., Griffin, J. L., \& Krowinski, A. C. (2003). Stressors for gay men and lesbians: Life stress, gay-related stress, stigma consciousness, and depressive symptoms. Journal of Social and Clinical Psychology, 22(6), 716-729. https://doi.org/10.1521/jscp.22.6. 716.22932

Liben, L. S., Bigler, R. S., Ruble, D. N., Martin, C. L., \& Powlishta, K. K. (2002). The developmental course of gender differentiation: Conceptualizing, measuring, and evaluating constructs and pathways. Monographs of the Society for Research in Child Development, 67(2), 1-183. https://doi.org/10.1111/1540-5834.t01-1-00188

Maio, G. R., \& Esses, V. M. (2001). The need for affect: Individual differences in the motivation to approach and avoid emotions. Journal of Personality, 69(4), 583-614. https://doi.org/10.1111/1467-6494.694156

Malouff, J. M., Thorsteinsson, E. B., Schutte, N. S., Bhullar, N., \& Rooke, S. E. (2010). The Five-factor model of personality and rela- 
DRUŠ. ISTRAŽ. ZAGREB GOD. 29 (2020), BR. 3, STR. 413-430

BRKIĆ-JOVANOVIĆ, N. ET AL.:

RELATIONSHIP... tionship satisfaction of intimate partners: A meta-analysis. Journal of Research in Personality, 44(1), 124-127. https://doi.org/10.1016/j.jrp.2009. 09.004

Mark, K. P., Garcia, J. R., \& Fisher, H. E. (2015). Perceived emotional and sexual satisfaction across sexual relationship contexts: Gender and sexual orientation differences and similarities. The Canadian Journal of Human Sexuality, 24(2), 120-130. https://doi.org/10.3138/cjhs.242-A8

Markey, P., Markey, C., Nave, C., \& August, K. (2014). Interpersonal problems and relationship quality: An examination of gay and lesbian romantic couples. Journal of Research in Personality, 51, 1-8. https:// doi.org/10.1016/j.jrp.2014.04.001

Matud, M. P., Bethencourt, J. M., \& Ibáñez, I. (2014). Relevance of gender roles in life satisfaction in adult people. Personality and Individual Differences, 70, 206-211. https://doi.org/10.1016/j.paid.2014.06.046 Mihić, I., \& Huić, A. (2012). Uloga potrebe za emocijama u pokazivanju ljubavi muškaraca i žena (The role of need for affect in the ways men and women show love to each other). Primenjena psihologija, 5(3), 279-294. https://doi.org/10.19090/pp.2012.3.279-294

Muthén, L. K., \& Muthén, B. O. (2015). Mplus user's guide (1998-2015). Muthén \& Muthén: Los Angeles, CA.

Peplau, L. A., \& Beals, K. P. (2004). Lesbians, gay men, and bisexuals in relationships. In J. Worell (Ed.), Encyclopedia of women and gender (pp. 657-666). San Diego, CA: Academic Press.

Peplau, L. A., \& Fingerhut, A. W. (2007). The close relationships of lesbians and gay men. Annual Review of Psychology, 58, 405-424. https:// doi.org/10.1146/annurev.psych.58.110405.085701

Sadikaj, G., Moskowitz, D. S., \& Zuroff, D. C. (2015). Felt security in daily interactions as a mediator of the effect of attachment on relationship satisfaction. European Journal of Personality, 29(2), 187-200. https://doi.org/10.1002/per.1988

Schoenfeld, E. A., Loving, T. J., Pope, M. T., Huston, T. L., \& Štulhofer, A. (2017). Does sex really matter? Examining the connections between spouses' nonsexual behaviors, sexual frequency, sexual satisfaction, and marital satisfaction. Archives of Sexual Behavior, 46(2), 489-501. https://doi.org/10.1007/s10508-015-0672-4

Soler, J. H., Caldwell, C. H., Córdova, D., Harper, G., \& Bauermeister, J. A. (2018). Who counts as family? Family typologies, family support, and family undermining among young adult gay and bisexual men. Sexuality Research and Social Policy, 15(2), 123-138. https://doi. org/10.1007/s13178-017-0288-7

Spence, J. T., \& Buckner, C. E. (2000). Instrumental and expressive traits, trait stereotypes, and sexist attitudes: What do they signify? Psychology of Women Quarterly, 24(1), 44-62. https://doi.org/10.1111/ j.1471-6402.2000.tb01021.x

Spence, J. T., Helmreich, R. L., \& Stapp, J. (1974). The Personal Attributes Questionnaire: A measure of sex role stereotypes and masculinity-femininity. JSAS Catalog of Selected Documents in Psychology, 4, 43. https://doi.org/10.1037/t02466-000

Stracuzzi, T. I., Mohr, J. J., \& Fuertes, J. N. (2011). Gay and bisexual male clients' perceptions of counseling: The role of perceived sexual 
DRUŠ. ISTRAŽ. ZAGREB GOD. 29 (2020), BR. 3, STR. $413-430$

BRKIĆ-JOVANOVIĆ, N. ET AL.:

RELATIONSHIP... orientation similarity and counselor universal-diverse orientation. Journal of Counseling Psychology, 58(3), 299. https://doi.org/10.1037/ a0023603

Strickland, B. (2010). Handbook on gender roles: Conflicts, attitudes and behaviors. Feminist Collections, 31(1/2), 33.

Yucel, D. (2018). The dyadic nature of relationships: Relationship satisfaction among married and cohabiting couples. Applied Research in Quality of Life, 13(1), 37-58. https://doi.org/10.1007/s11482-017-9505-z

\section{Zadovolistvo vezom kod homoseksualnih i heteroseksualnih parova: dijadski model}

Nina BRKIĆ-JOVANOVIĆ

Medicinski fakultet, Sveučilište u Novom Sadu, Novi Sad

Milica LAZIĆ, Ivan JERKOVIĆ, Ivana MIHIĆ

Filozofski fakultet, Sveučilište u Novom Sadu, Novi Sad

Bojana PERIĆ-PRKOSOVAČKI

Medicinski fakultet, Sveučilište u Novom Sadu, Novi Sad

Ukorijenjena u Hustonovom (2000) modelu prilagodbe u romantičnim vezama, svrha je ove studije bila provjeriti postoje li razlike $u$ individualnim značajkama i značajkama veza između četiriju skupina sudionika koje su formirane na temeliu spola i seksualne orijentacije te utvrditi prediktivnu vrijednost jednih i drugih značajki za zadovoljstvo vezom. Uzorak je obuhvatio ukupno 100 heteroseksualnih parova i 50 muških i 50 ženskih homoseksualnih parova. Od pojedinačnih karakteristika potreba za emocijama je važni prediktor zadovoljstva romantičnom vezom i postiže značajne aktorske i partnerske učinke na zadovoljstvo vezom u svim podskupinama, osim kod heteroseksualnih žena. Osobni izraz ljubavi također postiže aktorski i partnerski učinak na zadovoljstvo vezom heteroseksualnih i homoseksualnih muškaraca. Učinak partnerovog izraza ljubavi (aktorski učinak) na zadovoljstvo odnosa zabilježen je u svim skupinama, osim kod homoseksualnih muškaraca. Ova studija nudi mogućnost integriranja znanja o razlikama između heteroseksualnih i homoseksualnih parova $u$ kontekstu modela prilagodbe u romantičnim vezama.

Ključne riječi: zadovoljstvo romantičnom vezom, seksualna orijentacija, individualne razlike, značajke veze, dijadski model

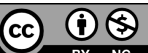

Međunarodna licenca / International License: Imenovanje-Nekomercijalno / Attribution-NonCommercial 